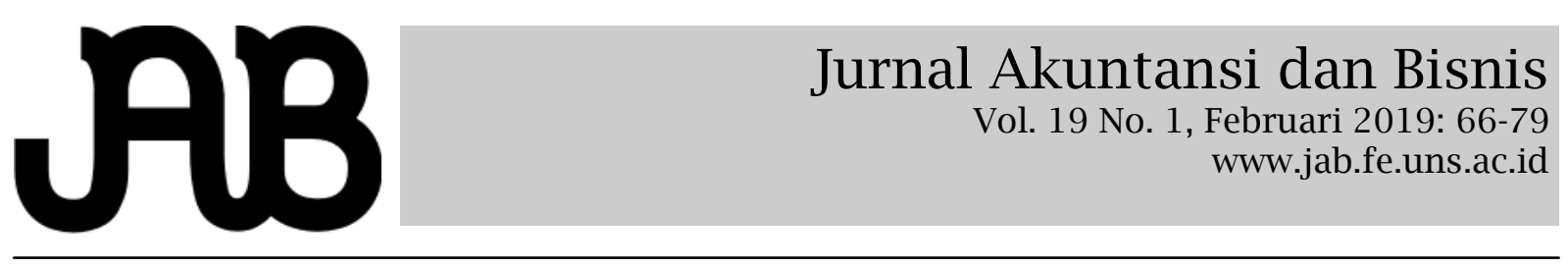

\title{
CORPORATE GOVERNANCE AND FIRM-SPECIFIC CRASH RISK: EVIDENCE FROM INDO- NESIAN FIRMS IN 2016
}

YOSUA SIHOMBING (yosua.sihombing@ui.ac.id )

VERA DIYANTY (vera.diyanti@ui.ac.id)

Department of Accounting, Faculty of Economics and Business, Universitas Indonesia, Indonesia

\begin{abstract}
A B S T R A C T
This research is aimed at investigating whether several dimensions of corporate governance mechanism, namely family ownership, accounting opacity, and Board of Commissioners effectiveness, have effect on one-year-ahead stock price crash risk. Hypothesis test is conducted in 2017 using cross section regression analysis with 277 samples of non-financial firms listed on Indonesia Stock Exchange in 2016. The result of this research does not show that family ownership and accounting opacity have any effect on firm-specific crash risk. Moreover, the result of this research finds that Board of Commissioners effectiveness has negative effect on firm-specific crash risk. This finding supports the notion that sound corporate governance system increases monitoring activities. This, in turn, decreases the tendency of managers to hide and accumulate bad news from outsiders. Hence, reducing firm-specific crash risk. Keywords: crash risk, corporate governance, agency risk, information environment.

Penelitian ini bertujuan untuk menginvestigasi apakah tiga dimensi mekanisme tata kelola perusahaan, kepemilikan keluarga, accounting opacity dan efektivitas Dewan Komisaris, berdampak terhadap 1-year-ahed stock price crash risk. Penelitian ini menemukan bahwa efektivitas Dewan Komisaris berpengaruh negatif terhadap firmspecific crash risk. Temuan ini mendukung suatu pernyataan bahwa sistem tata kelola perusahaan yang baik dapat meningkatkan kegiatan pemantauan. Hal ini pada akhirnya akan mengurangi kecenderungan manajer untuk menyembunyikan berita buruk dari outsiders. Namun Demikian, penelitian belum ditemukan bukti yang mendukung hubungan antara kepemilikan keluarga dan opacity akuntansi dan firm-specific crash risk.
\end{abstract}

Kata kunci: crash risk, tata kelola perusahaan, agency risk, information environment

\section{INTRODUCTION}

Recent academic studies have been putting much attention on firm-specific crash, arguing that withholding negative information from investor leads to firm-specific crash. These studies suggest that managers, due to their concern over their career and short-term compensation, will hoard negative news concerning company's performance. These bad news, however, can only accumulate to a certain level where managers can no longer withhold the bad news (Chen et al., 2001; Jin and Myers, 2006; Kothari et al., 2009). When this happens, all the negative information that was previously known only to managers are revealed to the public all at once, resulting in a firm-specific crash - an extreme negative return in the distribution of returns (Chen et al., 2001; Jin and Myers, 2006; Kothari et al., 2009).

In Indonesia, one of the most renowned case of company's management that was found guilty of hiding negative news from investors is Perusahaan Gas Negara in 2006. The management of the company, in September 2006, learned that the company's performance will not be as good as initially predicted. However, the management intentionally kept the news away from the market and the shareholders. When the news was finally released in January 2007 the consequence was severe. The stock price of Perusahaan Gas Negara 
fell $23.36 \%$ on the day following the release of the bad news ("BAPEPAM:Pelaku Kasus PGN," 2007).

Several researches have provided the empirical evidence to support the theory that stockpiling bad news leads to firmspecific stock price crash. These were done by showing that tax avoidance activities, manipulation of accrual, or earnings management leads to higher crash risk because it increases managers' likelihood to hoard negative information (Hutton et al., 2009; Kim et al., 2011 ; Cohen et al., 2014). The research shows that the higher the agency risk - the likelihood that managers act not in the best interest of shareholders, the higher the risk of crash because managers have higher needs to hide negative information. Therefore, one way to reduce the risk of firm-specific crash is by reducing agency risk through monitoring of managerial behavior.

Corporate governance can help companies to set their objectives and provide means to achieve the objectives and monitoring function to ensure that managers are working towards achieving the objectives (OECD, 2015). In a company where effective corporate governance system is practiced, it could be expected that the interests of managers and shareholders are more aligned. In consequence, the likelihood that managers will have the need to hide negative information from shareholders is low. The argument is supported by several empirical evidences that show how an effective corporate governance enhances information disclosure by managements (see, for example, Xie et al., 2003; Klein 2002; Karamanou and Vafeas, 2005).

Drawing motivation from this issue, this study will try to see the effect of corporate governance on firm-specific crash risk. More specifically, how family ownership, accounting opacity, and Board of Commissioners effectiveness affect firmspecific crash risk. These three corporate governance dimensions are to be investigated because they are related to the level of monitoring performed in a company (Andreou et al., 2016).

Family shareholders are characterized by long investment horizon and large ownership. This gives family shareholders more economic incentive to monitor managerial behavior because family shareholders benefit from the increase of company's fundamentals and their wealth depends on the firm's performance (Demsetz and Lehn, 1985; Stein , 1988). However, family ownership creates another problem between controlling and minority shareholders. Agency problem between controlling and minority shareholders, in turn, will create the need for controlling shareholders to hide information from minority shareholders.

Financial transparency is an important corporate governance mechanism in mitigating agency risk because it reduces information asymmetry between managers and shareholders. More transparent financial information gives investors more ability to look into the company's activities through financial information (McAllister, 2003). Consequently, more opaque financial reporting is expected to increases the risk of firm-specific crash as the financial information's ability to reduce information asymmetry is reduced.

In a company organizational structure, the board functions as a body that monitors managerial performance and ensures that managers provide an acceptable return for shareholders (OECD, 2015). In Indonesia the supervisory function is held by Board of Commissioners (BoC) where BoC has the responsibilities to monitor and to advise Board of Directors in carrying out its responsibilities. Consequently, an effective BoC will be better at overseeing the company's management. In a company where the Board of Commissioners functions effectively, therefore, it is expected that the agency risk is lower and the risk of stock price crash is lower as well.

This research is similar to the previous research done by Andreou et al. (2015) that tried to see the effect of four corporate governance dimensions on firmspecific crash risk. This research modified the previous research by changing the focus of the effect of institutional ownership to family ownership. The involvement of institutional investors is not prevalent in Indonesia. For example, the amount invest- 
ed in equity market by life insurance only accounted to $2 \%$ of total market capitalization of the equity market (Otoritas Jasa Keuangan, 2017). On the other hand, family owned business accounted to more than $70 \%$ of the total companies in Indonesia (Diyanti, 2012). Therefore, modifying the research from institutional ownership to family ownership will be more relevant for Indonesia's capital market.

Most research into the determinants of firm-specific crash risk has been done in advanced economies. However, emerging markets like Indonesia are characterized with more inefficient financial market and undeveloped legal market as the environment for its corporate governance (Mobarek et al., 2008). It is, therefore, interesting to see determinants of firm-specific crash risk in emerging economies, something that previous researches have not performed. Moreover, the research on firmspecific crash in Indonesia market is also important because companies in Indonesia, as an emerging market, face greater crash risk due to limited external monitoring and more opaque financial information (Cheng et al., 2014; Jin and Myers, 2006).

This will be structured as the following: 1) literature review and hypothesis development; 2) research method; 3) results and analysis; 4) conclusion, limitations, and future research.

The result of this research does not show that family ownership and accounting opacity have any effect on firm-specific crash risk. This result is different from the previous research by Andreou et al. (2015) that showed positive relationship between accounting opacity and firm-specific crash risk. Moreover, the result of this research finds that Board of Commissioners effectiveness has negative effect on firmspecific crash risk. This finding supports the notion that sound corporate governance system increases monitoring activities. This, in turn, decreases the tendency of managers to hide and accumulate bad news from outsiders. Hence, reducing firmspecific crash risk.

\section{LITERATURE REVIEW AND HYPOTHESIS DEVELOPMENT}

\section{Signalling Theory and Agency Theory}

Kothari et al. (2009) argue that managers' tendency to withhold bad news stems from the cost associated with disclosing bad news and the interests of the managers that are not aligned with the shareholders, an example is when managers hide information from shareholders due to their concern over their careers. Signalling theory suggest that firms with low quality do not have do not have the incentive or rather discouraged to reduce the information asymmetry between insiders and outsiders of the firms as doing so will reduce the value of the firm. Therefore, whenever the insiders of a firm receive a bad news, they will have the incentives to not report the bad news (Godfrey et al., 2010).

Information asymmetry that results from separation of ownership and control leads to moral hazard problem, that is a condition when the managers have the incentives to pursue their own interests at the expense of the wealth of shareholders. Managers pursuing their own interest can take many forms including taking part in suboptimal investment, overcompensation, empire building and overstating financial performance (Ashbaugh-Skaife et al., 2006; Kim and Zhang, 2016). While pursuing their own interests, however, managers have to maintain their position of trust. Therefore, managers have to hide their self-serving activities by exploiting the information asymmetry.

\section{Corporate Governance and Crash Risk}

The mechanism Jin and Myers (2006) argue that in companies where there is a lack of accounting transparency about the performance of the company, managers can capture a portion of the company's cash flow. The theory follows that in order to keep their positions as managers, managers may manage earnings so that the negative information will not be revealed to shareholders. However, when the company is performing bad enough, managers will be unable to hide any more negative information and release it to shareholders. This theory argues that firm-specific stock crash occurs when a company releases the bad news to shareholders. Therefore, this theory con- 
cludes that withholding bad news from investor lead to firm-specific crash.

Firm-specific crash risk, therefore, stems from the likelihood that managers act not in the best interest of shareholders or, in other words, crash-risk stems from agency risk that faces corporations (Chen et al., 2001, Jin and Myers, 2006). Agency risk, in turn, is the result of information asymmetry between shareholders and managements (Jensen and Meckling, 1976). Meanwhile, corporate governance is a system which aim to align the conflicting interest between the shareholders and managers (Claessens and Yurtoglu, 2013). Therefore, to see the relationship between crash risk and corporate governance, one has to see how corporate governance can affect the agency risk of a company through monitoring activities.

There is a broad set of literatures that find corporate governance can reduce agency risk by monitoring management's activities. Xie et al. (2002), Klein (2002), and Karamanou and Vafeas (2005), for example, find empirical evidence that more effective corporate governance reduces information asymmetries which in turn reduces agency risk. Xie et al. (2002) finds that financial literacy and past experience of BoD and Audit Committee increase the monitoring activities, hence reducing management's tendency to hide information and manage earnings. Klein (2002) finds that more independent audit committees perform better monitoring activities which in turn reduce earnings management and increase flow of information. Karamanou and Vafeas (2005) find that in a company that is better governed, management's forecasts, especially forecasting with bad news, are more precise because there are less information asymmetries.

\section{Hypothesis Development}

This research tries to see the effect of several corporate governance attributes on firm-specific crash risk of publicly listed companies in Indonesia. Previous research shows that the higher the agency risk - the likelihood that managers act not in the best interest of shareholders, the higher the risk of crash because managers have higher needs to hide negative information. Therefore, firm-specific crash risk can be reduced by reducing agency risk. Claessens and Yurtoglu (2013) define corporate governance as a system which aim to align the conflicting interest between the shareholders and managers. The implementation of good corporate governance, hence could be expected to reduce agency risk through monitoring activities.

There are several attributes of corporate governance mechanism that have previously been known to be designed to increase the monitoring of management's behavior which in turn reduce agency risk (Ashbaugh-Skaife et al, 2006). These attributes concern the three dimensions of corporate governance, these include ownership structure, accounting opacity, and board effectiveness. This research differs from previous research as it tries to see the effect of ownership structure that is most common in Indonesia, family ownership.

Ownership structure is closely linked to the degree of monitoring by shareholders. Previous research shows that investors with longer investment horizons and more shares on a company have more economic incentives to perform monitoring activities. Family investors are characterized by these two characteristics. Moreover, family investors are also better informed due to their lengthy tenure on the company they have their shares in. With more economic incentives and better ability to monitor managerial behavior, it is expected that family ownership can better align the interest of managers and controlling shareholders.

A research by Srinidhi and Liao (2014) finds that family-owned firms in the United States exhibit less likelihood to experience firm-specific crash. In line with this finding is the study by Cascino (2011) that finds family-owned companies provide better quality of accounting information. These findings suggest that the long-term focus of the shareholders of family firms reduces the proclivity of managers to act in opportunistic behavior. Therefore, in this kind of firms, managers have lesser need to hide bad news from shareholders which in turn reduces firm-specific crash risk.

However, Jabeen and Shah (2011) ar- 
gue that families as controlling shareholders may reduce or delay the release of information in order to be able to expropriate the wealth of minority shareholders. This argument is also supported by the findings by Huang and Zhang (2011) that find family firms in China exhibit lower financial reporting quality. Therefore, using the same argument that hiding information away from the public can increase the firmspecific crash risk, it is likely that family ownership results in higher firm-specific crash risk.

These two conflicting ideas of the result of family ownership on monitoring level are not strange. This is because there are currently two competing theories that guide the research on the topic of family ownership, namely alignment theory and entrenchment theory (Wang, 2006). These two theories put emphasize on two different agency problems with alignment theory emphasizing the conflict between owners and managers (Type I) and entrenchment theory emphasizing the conflict between the family and other shareholders (Type II) (Krishnan and Peytcheva, 2017). Alignment theory predicts that conflicts between management and shareholders in family firm will be reduced because there is less separation between ownership and control (Anderson and Reeb 2003). In contrast, entrenchment theory suggest that family ownership creates incentives and opportunities for family shareholders to expropriate wealth from minority shareholders (Krishnan and Peytcheva, 2017)

Considering these two conflicting effect of family ownership on firm-specific crash risk, the hypothesis of this research is:

H1: Family ownership is related with firmspecific crash risk

Accounting information is an important corporate governance mechanism in mitigating agency risk because it reduces information asymmetry between managers and shareholders. Lara et al (2009) argues that transparent accounting information provides an early warning to governance bodies when a firm is performing badly which then encourage investigation. Thus, accounting transparency can reduce the like- lihood of firm-specific crash by giving an early warning to when management's activities deviate from maximizing shareholder's welfare. More opaque financial reports, on the other hand is expected to inhibit the flow of information towards the stakeholders. Consequently, more opaque financial reports are expected to increase the firmspecific crash risk.

H2: Accounting opacity is negatively related with firm-specific crash risk

In a company, the board structure functions as a body that monitors managerial performance and ensures that managers provide an acceptable return for shareholders (OECD, 2015). The need of a supervisory board as an organ in an organization stems from the agency problem that exist as a result of separation of ownership and control (Peij et al, 2012). According to Fama and Jensen (1983) supervisory board is necessary to counteract the managerial opportunism that may arises as the result of information asymmetry. In addition, the supervisory board also adds value to the firm by providing advice to managers (Geletkanycyz and Boyd, 2011). In a company where the board functions effectively, therefore, its monitoring activities are also performed better, hence reducing managers' incentives to hide bad news.

H3: Board of Commissioners effectiveness is negatively related with firm-specific crash risk

\section{RESEARCH METHOD Sample and Data}

To conduct the research, this research uses only secondary data that are available to the public. The data are collected from several sources, including Thomson Reuters, firm annual reports, and Indonesia Capital Market Directory (ICMD). The population of this research is the entirety of limited liability companies, excluding financial services companies, that are listed in Indonesia Stock Exchange in 2016. In order to ensure that the research purposes are fulfilled, purposive sampling method is used to select samples. Following Similar to the previous research on the topic of crash risk by Andreou et al. (2015) and Kim and 
Zhang (2016), samples used in this research are non-financial firms that have at least 26 weeks of stock returns in one year and are not firms with negative equity value. The year 2016 is chosen as the period of the research because the year 2016 is the most recent year with the complete onyear stock price data available.

\section{Research Model}

To test the hypotheses of this research, the following regression model is used:

\begin{tabular}{|c|c|}
\hline & 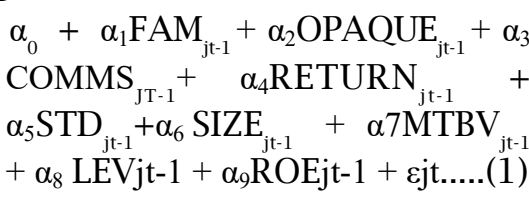 \\
\hline NCSKEW $_{j \mathrm{jt}}$ & $\begin{array}{l}\text { : Negative cond } \\
\text { ness of firm } j \text { on }\end{array}$ \\
\hline FAM $_{\mathrm{jt}-1}$ & $\begin{array}{l}\text { : Percentage of shared owned } \\
\text { by family of firm } j \text { during } t-1 \\
\text { period }\end{array}$ \\
\hline OPAQU & $\begin{array}{l}\text { Three-year sum of discre- } \\
\text { tionary accruals of firm } j \text { dur- } \\
\text { ing } t-1 \text { period }\end{array}$ \\
\hline $\mathrm{CON}$ & $\begin{array}{l}\text { : Board of Commissioners ef- } \\
\text { fectiveness that is measured } \\
\text { by ASEAN Corporate Govern- } \\
\text { ance Scorecard of firm } j \text { dur- } \\
\text { ing } t-1 \text { period }\end{array}$ \\
\hline RETURN $_{\mathrm{jt}-1}$ & $\begin{array}{l}\text { : Average weekly firm-specific } \\
\text { return of firm } j \text { during } t-1 \text { pe- } \\
\text { riod }\end{array}$ \\
\hline STL & $\begin{array}{l}\text { : Volatility of weekly firm- } \\
\text { specific return of firm } j \text { dur- } \\
\text { ing } t \text { - } 1 \text { period }\end{array}$ \\
\hline SIZE & $\begin{array}{l}\text { al logarithm of firm's } \\
\text { value of firm } j \text { during } t \\
\text { d }\end{array}$ \\
\hline MTE & $\begin{array}{l}\text { : Ratio of market to book val- } \\
\text { ue of firm's equity of firm } j \\
\text { during } t-1 \text { period }\end{array}$ \\
\hline & $\begin{array}{l}\text { : Leverage of firm } j \text { during } t-1 \\
\text { period }\end{array}$ \\
\hline ROE & : Return \\
\hline
\end{tabular}

The regression model in this research employs one-year period of lag between the corporate governance variables and the dependent variable. This is done in order to avoid the simultaneous endogeneity problems which previous research shows could occur should the dependent and independent variables are on the same period (Bhagat and Bolton, 2008; Andreou et al.,
2015). The model followed the model previously used by Andreou et al., (2015) as the model can captures the effect of multiple corporate governance dimensions rather than just one dimensional. Differing from the previous research, this research use the variable of family ownership, as oppose to institutional ownership, to better capture the ownership structure of Indonesian companies.

\section{Variable Operationalization Dependent Variable}

In accordance with prior research by Chen et al. (2000), the likelihood that a firm will deliver an extreme negative return or experiencing firm-specific crash can be measured by calculating the negative conditional skewness (NCSKEW) of the distribution of firm-specific return of that year. Negative conditional skewness is used because a negatively skewed distribution of returns shows that the firm has more return that are significantly below the mean of the distribution. Therefore, negative conditional skewness can measure the probability to crash. NCSKEW is obtained by calculating the negative value of the third moment of weekly returns and dividing it by the standard deviation of weekly returns raised to the third power.

$$
N C S K E W_{j t}=-\left[n(n-1)^{\frac{3}{2}} \sum W_{j t}^{3}\right] /[n-1)(n-2)\left(\sum W_{j t}^{2}\right)^{\frac{3}{2}}
$$

Equation (2) is used to calculate the negative conditional skewness of firm $j$ in week $t$. Since the firm-specific crash risk is measured by the negative conditional skewness, a positive value of NCSKEW corresponds to a stock being more likely to experience crash, that is the stock has a negatively skewed distribution of returns. Moreover, a larger value of NCSKEW indicates a higher risk of crash. On the other hand, a negative value of NCSKEW corresponds to a positively skewed distribution of return, that is the stock is more likely to have extreme positive returns.

To calculate Equation (2), the data of weekly firm-specific return are needed. Firm-specific return is used in calculating firm-specific crash risk because using the 
firm's actual return instead will include the effect of market performance as the factor that affects firm-specific crash risk (Hutton et al., 2009). To obtain weekly firm-specific return the following regression model is used to. The regression model sees actual firm returns as the function of market return and firm-specific return. Weekly firm specific-return, denoted by the variable $W$, is obtained from the following regression.

$\begin{aligned} \mathrm{r}_{\mathrm{jt}}=\alpha_{1}+\beta_{1} \mathrm{r}_{\mathrm{m}(\mathrm{t}-2)}+\beta_{2} \mathrm{r}_{\mathrm{m}(\mathrm{t}-1)}+\beta_{3} \mathrm{r}_{\mathrm{mt}}+\beta_{4} \mathrm{r}_{\mathrm{m}(\mathrm{t}+1)}+\beta_{5} \mathrm{r}_{\mathrm{m}(\mathrm{t}+2)} & +\varepsilon_{\mathrm{t}}\end{aligned}$ whereas $r_{j t} i s$ the weekly return of firm's $j$ stock in week $t$ while $\mathrm{r}_{\mathrm{mt}}$ is the market index return in week $t$. Weekly return of firm's $j$ stock in week $t$ is obtained from calculating the difference between stock price on the Wednesday of week $t$ and $t-1$ divided by the price on the Wednesday of $t$ 1. In the case of Indonesia, market index return is the return of Jakarta Composite Index. To obtain weekly market index return, the difference between the value of Jakarta Composite Index on the Wednesday of week $t$ and $t-1$ is divided by the value of Jakarta Composite Index on the Wednesday of $t-1$. Following prior research by Scholes and Williams (1977), lead and lag terms are included for the market index return in order to capture the return of firms with low trading volume. Weekly returns are chosen in this research because weekly return reduces the biases that exist in the data of daily returns. The firm-specific return of firm $j$ and week $t$ is obtained from $\mathrm{Wjt}=\mathrm{ln}$ $(1+€ \mathrm{jt})$.

\section{Independent Variables Family Ownership}

This research adopts the first definition of family ownership that was used by Arifin (2003) in his research. Arifin (2003), defines that by definition, all companies with individual ownerships of more than 5\% are considered family ownedArifin (2003) defines family as all individuals and corporations whose ownerships are recorded, in the case of Indonesia, all ownerships that are more 5\% are recorded. The ownership data is obtained from Indonesia's Stock Exchange's Report on Security Ownership 5\% or more as at 29 December 2015. This definition of family ownership excludes the ownerships by publicly listed companies, the state, financial institutions (e.g. insurance companies, pension funds, banks, and cooperations, and the public (any individuals whose ownerships are not recorded). This definition of family ownership by Arifin (2003) is used because this definition covers the most shareholders under the definition of family, which includes individuals, local companies, and foreign companies.

\section{Accounting Opacity}

Prior research by Hutton et al. (2009) (5) and Kim et al. (2014) suggest that firms having more discretionary accruals are more prone to exercising earnings management, hence impeding the flow of information from the management to the shareholders and the public.

Firstly, modified Jones model (Dechow, Sloan, and Sweeney, 1995) is applied to distinguish between normal accruals and discretionary accruals. From the data gathered of the companies used in this research, the following regression is used:

$\frac{T A C C_{j t}}{T A_{j t-1}}=\alpha \frac{1}{T A_{j t-1}}+\beta_{1} \frac{\Delta S A L E_{j t}}{T A_{j t-1}}+\beta_{2} \frac{P P E_{j t}}{T A_{j t-1}}+\varepsilon_{j t}$

TACCjt : Total accruals

ASSETSjt- $i$ : Total assets

$\triangle S A L E_{j} \quad$ : Change in sales from the previous years

PPEjt : Total property, plant, and equipment

$\triangle$ RECEIVA : Change in receivables from $B L E_{j t} \quad$ the previous years

The estimation is done by using cross -section regression on each industry of the sample's firms on each year. This is following Hutton et al. (2009) that Modified Jones Model will have better result by regressing it on its industry rather than with timeseries. From this regression, discretionary accruals (DisAcc) is obtained by calculating the error of regression (4).

Prior research by Dechow, Sloan and Sweeney (1995) suggests that managers who manipulate their earnings started manipulating the information of their finan- 
cial statements three years prior to being detected. The research shows that managers gradually increase their discretionary accruals approaching the year earnings manipulation. Moreover, the research also suggests that overstated accruals in the year of earnings management is usually followed by a reversing negative accruals following the year of earnings management. Therefore, Hutton et al. (2009) measure the opacity of financial reporting as the three-year moving sum of the absolute value of annual discretionary accruals:

OPAQUE $_{\mathrm{jt}}=\operatorname{Abs}\left(\operatorname{DiscAcc}_{\mathrm{jt-1}}\right)+\operatorname{Abs}\left(\right.$ DiscAcc $\left._{\mathrm{jt-2} 2}\right)$ $+\operatorname{Abs}\left(\operatorname{DiscAcc}_{\mathrm{jt}-3}\right) \ldots \ldots \ldots \ldots \ldots \ldots . . .(5)$

The variable OPAQUE, therefore, is the proxy used in this research to measure the level of firm-specific information that is hidden from the shareholders.

The definitions of the variables of eqution and equation, for firm $j$ during year $t$ are as follow:

\section{Board of Commissioners Effectiveness}

The proxy used to measure the effectiveness of Board of Commissioners is the ASEAN Corporate Governance Scorecard. The scorecard is an assessment of corporate governance practice based on publicly available information which benchmarked the practice with international best practice (ACMF, 2017).

Equitable treatment of shareholders assessed in this scorecard measures the effectiveness of both Board of Directors and Board of Commissioners by assessing several aspects, including board duties and responsibilities, board structure, board processes, people on the board, and board performance. There are a total of 65 questions used in the assessment, however, this research will only use questions that are related to Board of Commissioners. Questions that are not related to Board of Commissioners are omitted.

There are 48 questions that will be used to assess Board of Commissioners effectiveness. Each question will result in a "yes" or "no" answer, whereby a "yes" is one point for the company and a "no" is zero point for the company. Therefore, the assessment will result in a maximum score of 48 or a minimum of 0 for each company. Higher result of the scoring indicates a more effective Board of Commissioners hence better monitoring activities are expected from the company.

\section{Control Variables}

This research uses several control variables to control the effects of variables that were known to affect the dependent variable. There are six control variables used in this research. Following prior research by Chen et al., (2001) and Kim et al., (2014) the control variables used in this research include firm's past average weekly return $($ RETURN), firm's past weekly return volatility (STD), firm size (SIZE), firm's Market to Book Value ration (MTBV), leverage (LEV), and Return on Equity (ROE). Pastreturn is controlled because firm stock which has been experiencing higher returns also has the higher negative skewness, or firm-specific crash risk. Firm's past weekly return volality is included because volatile stocks face higher crash risk. The volatility of a stock is calculated as the standard deviation of the firm's weekly firm specific return (Wjt). Chen et al. (2001) finds the bigger the size of the company, the more negative the skewness of the company. SIZE is calculated by calculating the natural logarithm of firm's market value of equity.

\section{Regression Result}

Table 2 shows the result of ordinary least square regression. The result shows that most of the coefficients of the variables are consistent with the expected direction of the impact of the variables on future firmspecific crash risk. Two exceptions are for the variable control OPAQUE and LEV which are expected to have positive signs but show negative signs.

Table 2 shows that family ownership has no statistically significant effect on firm-specific crash risk. This finding is different from previous research by Srinidhi and Liao (2014) that finds that familyowned firms have lower likelihood to crash because family ownership provides better incentives to monitor managerial activities. This finding also does not support the no- 
tion that family-owned firms have more tendency to delay the release of information from minority shareholders in order to expropriate from them (Jabeen and Shah, 2011), which according to Jin and Myers (2006) leads to higher risk of firmspecific crash.

This finding that family ownership does not have significant effect on firmspecific crash risk can be explained by the variable used in this research that does not differentiate different types of family ownership. As explained by Attig et al. (2006), family ownership with larger gap between controlling rights and cash flow rights are more likely to incur higher Type II agency cost. Even though some prior studies can reach a conclusive finding on the effect of family ownership without taking into account the different types of familyownership that exist in different compa- nies, other studies find conflicting findings of the effect of family ownership when differentiating the type of family ownership in the companies observed. That is to take into account the potential Type II agency problems.

For example, Cascino et al. (2010) reach a conclusion that the presence of a family alone, not taking into consideration the potential Type II agency problem, results on better quality of the financial reports produce by a listed firm in Italy. On the other hand, Diyanti et al. (2015) find that family ownership with higher level of Type II agency problem negatively affects the performance of the company. On the contrary, family-owned firms that reduces Type I agency problem were proved to have better performance. The same conflicting result was also found by Kang et al. (2014). Kang et al. (2014) find that related-party

Table 2.

Cross Section Regression Result

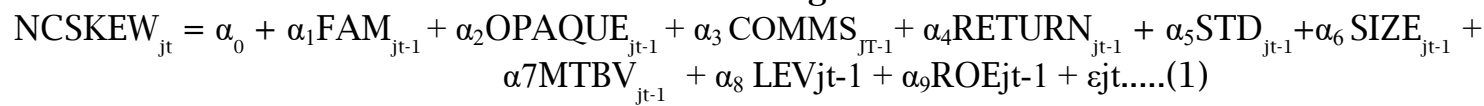

\begin{tabular}{|c|c|c|c|c|}
\hline Variable & $\begin{array}{l}\text { Predicted } \\
\text { Sign }\end{array}$ & Coefficient & P-value & Significance \\
\hline OPAQUE & $>0$ & -0.2895051 & 0.584 & \\
\hline FAM & ${ }^{1} 0$ & -0.0009317 & 0.676 & \\
\hline COMMS & $<0$ & -1.168736 & 0.043 & $*$ \\
\hline RETURN & $>0$ & 55.33697 & 0.039 & $*$ \\
\hline STD & $>0$ & 13.2623 & 0.003 & $*$ \\
\hline SIZE & $>0$ & 0.1366944 & 0.000 & $*$ \\
\hline ROE & $<0$ & -0.3571689 & 0.108 & \\
\hline MTBV & $>0$ & 0.0219496 & 0.053 & \\
\hline LEV & $>0$ & -0.4086178 & 0.155 & \\
\hline CONS & & -3.043441 & 0.000 & \\
\hline Observation: 277 & \multicolumn{2}{|c|}{ Prob $>F=0.0000$} & Adj R-squ & red 0.1312 \\
\hline
\end{tabular}

Notes: Values with * indicates significant relationship at 5\% ; NCSKEW: firm specific crash risk as measured by the negative conditional skewness of the distribution of weekly firm-specific return; OPAQUE: the three years moving average of firm's discretionary accruals; FAM: variable that shows percentage of shares owned by family; COMMS: the score of the effectiveness of firm's Board of Commissioners based on ASEAN CG Scorecard divided by the maximum score; RETURN: the average of firm-specific weekly return during the previous year; STD: the volatility of firm-specific weekly return during the previous year; SIZE: the natural logarithm of firm's market value of equity; ROE: firm's return before extraordinary items divided by book value of equity; MTBV: the ratio of firm's market value of equity to its book value; LEV: the ratio of firm's liabilities to its assets 
transactions are more frequent in family firms with Type II agency problem compared to other family firms. These suggest that depending on the type of agency problems that exist in a family-owned firm, the effect of family ownership may differ or even conflicting. Therefore, one possible reason that family ownership does not have significant effect on firm-specific crash risk in this research is because the effect of family ownership is different for family firms with Type I and Type II agency problems. In other words, the effect of family ownership on firm-specific crash risk cannot be generalized for firms with different level of Type II agency cost.

Cheng (2014) notes that the fundamental findings in the research of family firms suggest that family owned companies perform better than non-family firms. However, most of these findings are based on the evidence from Western European countries that have better shareholder protection and country-level legal infrastructure, which in turn reduce Type II agency problems (Maury, 2006). On the other hand, Cheng (2014) notes that most research that examine the effect of Type II agency problem is done in China. He further explains that this is because Chinese family owners have a significant wedge between voting rights and cash flow rights, which can motivate the founding family to expropriate the minority shareholders. The same remark was also made by Claessens et al. (1999) about the characteristics of family firms in Indonesia. In other words, Type II agency problems are more prevalent in Indonesia than in advanced economies.

The existence of Type II agency problem on family-owned firms affect the flow of information that are allowed to be released by controlling shareholders to the public (Jabeen and Shah, 2011). This is as opposed to the notion that managers are the party that inhibits the flow of information to the public. Jabeen and Shah (2011) explain that in a Type II agency problem, controlling shareholders may reduce or delay the release of information in order to be able to expropriate the wealth of minority shareholders. This argument is also supported by the findings by Huang and Zhang (2011) that find family firms in China, where Type II agency problems are more prevalent, exhibit lower financial reporting quality. Therefore, using the same argument that hiding information away from the public can increase the firmspecific crash risk, it is likely that family firms with Type II agency problem has higher firm-specific crash risk. This is in contrast to the research by Srinidhi and Liao (2014) that argues that family ownership, due to its ability to reduce Type I agency problem, faces lower firm-specific crash risk.

In conclusion, general findings in the topic of family ownership in advanced economies like in Europe or the US suggest that family ownership leads to better monitoring of managerial behavior which in turn reduces conflict between owners-managers. However, these findings are generally based on the condition where the state can better protect their shareholders which reduces Type II agency problem. Therefore, as argued by Cheng (2014), countries in advanced economies do not face significant Type II agency problem in their familyowned firms. In a country where Type II agency problem is more prevalent for family firms, a distinction between family firms with Type I or Type II agency problem is necessary in order to gain better understanding of the effect of family ownership on a certain firm's outcome. The insignificant effect of family ownership on firmspecific crash risk in Indonesia might indicate that family ownership with Type II agency problem has the opposite effect to family firms that reduce Type I agency problem. This is because in family firms with Type II agency problems, controlling shareholders have more incentive to hide information away from minority shareholders, thus increasing firm-specific crash risk. does not have significant effect on firmspecific crash risk. This finding can be explained by the variable used in this research that does not differentiate different types of family ownership. As explained by Attig et al. (2006), family ownership with larger gap between controlling rights and cash flow rights are more likely to incur higher Type II agency cost. Even though 
some prior studies can reach a conclusive finding on the effect of family ownership without taking into account the different types of family-ownership that exist in different companies, other studies find conflicting findings of the effect of family ownership when differentiating the type of family ownership in the companies observed. That is to take into account the potential Type II agency problems. For example, Kang et al. (2014) find that relatedparty transactions are more frequent in family firms with Type II agency problem compared to other family firms. These suggest that depending on the type of agency problems that exist in a family-owned firm, the effect of family ownership may differ or even conflicting.

The insignificant effect of family ownership on firm-specific crash risk in Indonesia might indicate that family ownership with Type II agency problem has the opposite effect to family firms that reduce Type I agency problem. This is because in family firms with Type II agency problems, controlling shareholders have more incentive to hide information away from minority shareholders, thus increasing firmspecific crash risk. This notion is supported by the finding by Jabeen and Shah (2011) that finds that existence of Type II agency problem on family-owned firms affect the flow of information that are allowed to be released by controlling shareholders to the public. It is therefore necessary to differentiate different types of family ownership in order to gain better understanding of the effect of family ownership on a certain firm's outcome.

Table 2 shows that accounting opacity has negative and significant relation with firm-specific crash risk. This finding, therefore, cannot confirm the notion by Hutton et al. (2009) that argue that earnings management hinder the usefulness of accounting information to reduce information asymmetry by inhibiting the flow of information from the company to the public which in turn increases firm-specific crash risk.

As initially predicted, the regression result shows negative coefficient between the effectiveness of Boards of Commission- ers and firm-specific crash risk. Moreover, the regression result also shows statistically significant effect of the effectiveness of Board of Commissioners on firm-specific crash risk. The finding of this study thus supports the notion that Board of Commissioners that functions effectively has better ability to monitor managerial behavior. The better monitoring activities in turn reduces managerial opportunistic behavior thus reduces the need of management to hide information away from shareholders. In the end, firm-specific crash risk is reduced with a more effective Board of Commissioners.

This finding of Board of Commissioners effectiveness highlights the importance of Board of Commissioners as the monitoring force in a company. Board of Commissioners has the responsibility to safeguard shareholders' wealth by monitoring and managing potential conflicts of interest of management, board members and shareholders, including misuse of corporate assets. Moreover, the use of ASEAN CG Scorecard as a measurement of Board of Commissioners effectiveness also indicates that the cost borne by shareholders to ensure the best practice of Board of Commissioners should pay off with the reduced firm-specific crash risk.

\section{CONCLUSION}

The objective of this research is to find out the effect of corporate governance on firmspecific crash risk. The corporate governance mechanisms used in this research include ownership structure, accounting information, and Board of Commissioners. In order to do so, this study tries to find out the effect of family ownership, accounting opacity and Board of Commissioners effectiveness on future firm-specific crash risk. Using sample of 277 non-financial firms in Indonesia in 2016, three hypotheses are tested leaving one hypotheses to be proven.

This study finds that the Board of Commissioners effectiveness is negatively and significantly related to firm-specific crash risk. This suggests that Board of Commissioners that functions more effectively as the supervisory organ of a firm is 
able to better align the interest of the managers and the shareholders of a firm. This in turn reduce the agency problem in the firm, which means the managers are less likely to act in an opportunistic manner. Consequently, there is less need and incentive for managers to hide information from shareholders. Therefore, in this setting the firm is less likely to experience firmspecific crash risk. The use of ASEAN Corporate Governance Scorecard as a measurement of Board of Commissioners effectiveness which is based on international based practice shows the need for Board of Commissioners to go beyond what the national regulation requires.

\section{LIMITATIONS AND SUGGESTIONS}

In conducting this research, there are still some limitations that should be addressed for future researches that are related to this topic. (1)Tthe research only uses oneyear period as the observation period. Therefore, future research can add more to the observation period to increase the accuracy of the research. (2)This research only employs one measure of the risk of firmspecific crash risk. The increasing interest on the subject of this research has resulted in more variations available to measure the risk of firm-specific crash, such as down-to -up volatility which separates firm-specific return to those beyond and below the annual mean. Future researches can employ other measure to obtain better findings. (3) This research only measure the family ownership by the $1^{\text {st }}$ layer of ownership structure, did not tracing the family ownership until finding the ultimate ownership to determine family ownership. The future research can employ the ultimate ownership to determine the percentage of family ownership to get the more accurate result. The finding of this research highlights the importance to evaluate the effect of family ownership as family firms that face greater Type II agency problems and not. This is important especially knowing that firms facing Type II agency problems are more prevalent in Indonesia compared to countries with advanced economies. Furthermore, there is no reassessment from a third party of the scoring of the Board of
Commissioners' effectiveness which might dilute the accuracy and independence of the scoring.

\section{REFERENCES}

Arifin, Z. (2003). Masalah agensi dan mekanisme control pada perusahaan dengan struktur kepemilikan terkonsentrasi yang dikontrol keluarga: bukti dari perusahaan publik Indonesia. Unpublished Dissertation, FEUI Graduated Program in Management.

ASEAN Capital Markets Forum. ASEAN Corporate Governance Scorecard V.2.0. Retrieved . Last accessed on January 1, 2018, from http:// www.theacmf.org/ACMF/upload/ asean_cg_scorecard_12_may_2017.pd $\mathrm{f}$

Andreou, P. C., Antoniou, C., Horton, J., \& Louca, C. (2016). Corporate governance and firm-specific stock price crashes. European Financial Management, 22 (5), 916-956.

Ashbaugh-Skaife, H., Collins, D., LaFond, R., (2006). The effects of corporate governance on firms' credit ratings. Journal of Accounting and Economics, 42 (1), 203-243.

Attig, N., Fong, W. M., Gadhoum, Y., \& Lang, L. H. (2006). Effects of large shareholding on information asymmetry and stock liquidity. Journal of Banking \& Finance, 30(10), 2875-2892.

Bae, Kee-Hong., Lim, Chanwoo., Wei, K.C. John. (2006). Corporate governance and conditional skewness in the world's stock markets. Journal of Business 79(6), 2999-3028

Tempo Co. (2007). BAPEPAM: Pelaku Kasus PGN Mengarah ke Perseorangan (2007, February 14). Retrieved from https://bisnis.tempo.co/read/93778/ bapepam-pelaku-kasus-pgn-mengarah -ke-perseorangn

Bhagat, S., \& Bolton, B. (2008). Corporate governance and firm performance. Journal of Ccorporate Ffinance, 14(3), 257-273.

Cascino, S., Pugliese, A., Mussolino, D., \& Sansone, C. (2010). The influence of family ownership on the quality of accounting information. Family Business Review, 23(3), 246-265.

Chen, J. (2001). Ownership structure as corporate governance mechanism: Evidence from Chinese listed companies. Economics of Planning, 34(1), 5372.

Chen, J., Hong, H., Stein, J.C. (2001). Fore- 
casting crashes: trading volume, past returns, and conditional skewness in stock prices. Journal of Financial Economics 61 (3), 345-381.

Cheng, B., Ioannis, I., dan Serafeim, G. (2014). Corporate social responsibility and access to finance. Strategic Managemet Journal, 35(1), 1-23.

Claessens, S., dan Yurtoglu, B. B. (2013). Corporate Governance in Emerging Markets: A Survey. Emerging Markets Review, 15(C), 1-33.

Claessens, S., Djankov, S., \& Lang, L. H. (1999). Who Controls East Asian Corporations? (Vol. 2054). World Bank Publications.

Dechow, P. M., Sloan, R. G., \& Sweeney, A. P. (1995). Detecting earnings management. Accounting Rreview, 70(2), 193225.

Diyanti, Vera. (2012). Pengaruh kepemilikan pengendali akhir terhadap traksaksi pihak berelasi dan kualitas laba. Unpublished Dissertation. Program Pascasarjana Akuntansi, Universitas Indonesia, Depok.

Fama, E. F., \& Jensen, M. C. (1983). Separation of ownership and control. The Jjournal of Llaw and Economics, 26(2), 301-325.

Geletkanycz, M. A., \& Boyd, B. K. (2011). CEO outside directorships and firm performance: A reconciliation of agency and embeddedness views. Academy of Management Journal, 54(2), 335-352.

Godfrey, Jayne, Allan Hodgson, Ann Tarca, Jane Hamilton, dan Scott Holmes. (2010). Accounting Theory, 7th Ed. Brisbmane:. John Wiley \& Sons Australia, Ltd

Huang, J., Zhang, T. (2011). The accounting information quality in family firms: evidence from China. China Account. Finance Rev. 13, 1-62.

Hutton, A.P., Marcus, A.J., Tehranian, H. (2009). Opaque financial reports, R2, and crash risk. Journal of Financial Economics 94(1), 67-68.

Jabeen, M., \& Shah, A. (2011). A review on family ownership and information asymmetry. Africaln Journal of Business Management, 3 (35), 1355013558.

Jensen, M. C., \& Meckling, W. H. (1976). Theory of the Firm: Managerial Behavior, Agency Costs, and Ownership Structure. Journal of Financial Economics, 3 (4), 305-360.

Jin, L., Myers, S.C., (2006). R2 around the world: new theory and new tests.
Journal of Financial Economics 79 (2), 257-292.

Kang, M., Lee, H. Y., Lee, M. G., \& Park, J. C. (2014). The association between related-party transactions and controlownership wedge: Evidence from Korea. Pacific-Basin Finance Journal, 29, 272-296.

Karamanou, I., \& Vafeas, N. (2005). The association between corporate boards, audit committees, and management earnings forecasts: An empirical analysis. Journal of Accounting Rresearch, 43(3), 453-486.

Kim, J. B., \& Zhang, L. (2016). Accounting conservatism and stock price crash ris k: Fi r m-le ve l e vi dence. Contemporary Accounting Research, 33(1), 412-441.

Kim, Y., Li, H., \& Li, S. (2014). Corporate social responsibility and stock price crash risk. Journal of Banking \& Finance, 43, 1-13.

Klein, A. (2002). Audit committee, board characteristics and earnings management. Journal of Accounting and EConomics 33(3), 375-400.

Kothari, S. P., Shu, S., \& Wysocki, P. D. (2009). Do managers withhold bad news?. Journal of Accounting Research, 47(1), 241-276.

Krishnan, G., \& Peytcheva, M. (2017). The risk of fraud in family firms: Assessments of External Auditors. Journal of Business Ethics, 1-18.

Lara, J. M. G., Osma, B. G., \& Penalva, F. (2009). Accounting conservatism and corporate governance. Review of Aaccounting Ststudies, 14(1), 161-201.

Maury, B. (2006). Family ownership and firm performance: Empirical evidence from Western European corporations. Journal of Corporate Finance, 12(2), 321-341.

McAllister, J.P. (2003). Transparent reporting? It doesn't equal GAAP compliance. Strategic Finance, 84(9), 46-48

Mobarek, A., Mollah, A. S., \& Bhuyan, R. (2008). Market efficiency in emerging stock market: evidence from Bangladesh. Journal of Emerging Market Finance, $7(1), 17-41$.

OECD (2015). G20/OECD Principles of Corporate Governance. OECD Publishing.

Otoritas Jasa Keuangan. Statistik Dana Pensiun. Retrieved from http:// www.ojk.go.id/id/kanal/iknb/datadan-statistik/dana-pensiun/Pages/ Statistik-Dana-Pensiun---November2017.aspx

Peij, S. C., Bezemer, P. J., \& Maassen, G. F. 
(2012). The effectiveness of supervisory boards: an exploratory study of challenges in Dutch boardrooms. International Journal of Business Governance and Ethics, 7(3), 191208.

Scholes, M., \& Williams, J. (1977). Estimating betas from nonsynchronous data. Journal of Ffinancial Eeconomics, 5(3), 309-327.

Srinidhi, B., \& Liao, Q. (2014). Do U.S. family firms exhibit lower stock price crash risk? Working paper. University of Texas at Arlington

Wang, D. (2006). Founding family ownership and earnings quality. Journal of Aaccounting Rresearch, 44(3), 619656.

Xie, B., Davidson, W. N., \& DaDalt, P. J. (2003). Earnings management and corporate governance: the role of the board and the audit committee. Journal of Ccorporate Ffinance, 9 (3), 295-316. 